GLOBAL DEVELOPMENT AND ENVIRONMENT INSTITUTE

Working PAPER No. 06-04

\title{
Ethics and International Debt: A View from Feminist Economics
}

\author{
Julie A. Nelson
}

August 2006

Tufts University

Medford MA 02155, USA

http://ase.tufts.edu/gdae 


\title{
Ethics and International Debt: A View from Feminist Economics
}

\author{
Julie A. Nelson
}

Revised August 14, 2006. Presented at the conference “The Problem of Sovereign Debt,” sponsored by New School University and the Carnegie Council on Ethics and International Affairs, New York, November 1-2, 2005.

\begin{abstract}
Feminist scholars examine not only the gendered impacts of development programs whose design has been influenced by disciplines such as economics, but also the gendered biases that permeate the models and methods of the disciplines themselves. This essay draws on aspects of feminist critiques of economics, philosophy, psychology, law, and finance to analyze the way in which international debt is discussed. Feminist critiques raise serious questions about the rational choice framework that often undergirds scholarly discussions of "agents," “contract," "ethics,” and "capital and debt."
\end{abstract}

\section{Introduction}

An economist, a logician, and a scientist are on a train traveling north through Massachusetts. As the train crosses into Vermont, they look out the window and see a brown cow standing in a field.

"The cows in Vermont are brown," says the economist.

"At least one of the cows in Vermont is brown," corrects the logician.

"There is at least one cow in Vermont and at least one side of it is brown," corrects the scientist.

Economists, as we know, like to make assumptions-in this story, the economist makes an inference that far oversteps the facts at hand. But what do we see when we look out our own "train windows" at the international debt crisis? What assumptions do we make? How do we frame the issue of ethics and sovereign debt? What language do we use to describe it, and what models and images do we draw on in our analysis? One particular frame was evident in several of the papers prepared for a recent high-level conference on the topic "The Problem of Sovereign Debt."1 Reflecting on that conference, the purpose of this essay is to point out the limitations of the rational choice contract frame for the analysis of international debt, and to point towards more adequate alternatives.

\footnotetext{
${ }^{1}$ Sponsored by New School University and the Carnegie Council on Ethics and International Affairs, New York, November 1-2, 2005.
} 
When analysts use the rational choice contract frame they perceive the issue of ethics and international debt as, at its core, as a question of whether or not certain financial contracts should be enforced. Debt contracts may be conceived of as largely impersonal, rational, voluntary financial market agreements drawn up between selfinterested individual agents. Sometimes such contractual relations are treated, at least implicitly, as though they were largely separable from--or even ontologically prior to-social, political, and moral relations among flesh-and-blood human beings. This frame arises because "liberal man," the subject of much analytical philosophy, is considered to be a rational, morally responsible, and autonomous agent. Ethics, within this frame, is conceived of as primarily a matter of determining the proper set of principles for ensuring justice among such agents. Neoclassical economists have taken the image of "liberal man” some steps further. By developing refined conceptions of “economic man” and markets, economists have been able to build models that have been perceived as "rigorous" due to their elegance, generality, and precision. ${ }^{2}$ Because of this, economists' assumptions and methods are often now envied — and emulated — by many in other disciplines, including philosophy, law, and development studies.

The rational choice contract frame offered by traditional analytical philosophy and mainstream economics is, however, too narrow. Like a Procrustean bed, it results in some of the most interesting and pressing aspects of the issue of international debt being cut off and ignored.

How are terms like "agent," “contract," “ethics,” and “capital and debt," understood within standard approaches? How can these terms be more appropriately and more usefully understood, if gender-related biases in these disciplines are overcome? Feminist theory, as developed within the fields of economics, philosophy, psychology, finance, and law provides a much needed alternative perspective. Only by opening one's mind and being willing to shift one's perspective can is it possible to perceive the other "cows in Vermont," and examine the "sides" of those cows not immediately in our view.

\section{Two Problems}

But first, rather than launching into a more abstract discussion, observe that there are two obvious problems with trying to analyze the ethics of sovereign debt using the rational choice contract frame. The very issue of national debt itself and our concern about it raise anomalies that cannot be forced into this limited perspective.

\section{“Agents” and International Debt}

Often discussions of debt are cast in terms of the behaviors of discrete, welldefined, decision-making, morally responsible agents. This is the case, for example, in a

\footnotetext{
${ }^{2}$ See Meagher and Nelson (2004) for discussion of the similarities and differences between "economic man" and "liberal man."
} 
background paper for the abovementioned conference entitled "Ethical Issues Relevant to Debt,” authored by philosopher Christian Barry. In his formal analysis, Barry assumes the existence of such discrete agents, identifying them by such labels as "A," "B," "the debtor," "the creditor,” “one,” "him,” or "her” (2005, 19-22). While one is, of course, entitled to use abstraction and shorthand notations in developing an argument, one also needs to check back to be sure that nothing important has been lost along the way.

If we assume from the start that debt is all about "agents," something important has been missed. A very large, and presumably ethically-central group of people is utterly left out of analysis that proceeds in these terms. These are the children living in impoverished debtor nations. According to World Bank statistics, fully 43\% of the people living in Heavily Indebted Poor Countries (HIPCs) are under age fifteen. (World Bank, 2005). ${ }^{3}$ As expressed in a UNICEF report,

...It is necessary to give some voice, however inadequate, to the children of the developing world who have no other say in international economic dealings but who are so profoundly and permanently affected by them.... The fact that so much of today's staggering debt was irresponsibly lent and irresponsibly borrowed would matter less if the consequences of such folly were falling on its perpetrators. Yet now, when the party is over and the bills are coming in, it is the poor who are being asked to pay....

And when the impact becomes visible in rising death rates among children, rising percentages of low-birth weight babies, falling figures for the average weight-for-height of the under-fives, and lower school enrollment ratios among 6- to 11-year-olds, then it is essential to strip away the niceties of economic parlance and say that what has happened is simply an outrage against a large section of humanity.... Allowing world economic problems to be taken out on the growing minds and bodies of young children is the antithesis of all civilized behavior. Nothing can justify it. And it shames and diminishes us all. (UNICEF, 1989)

If one tries to locate children within Barry's essay, one comes up short. The notion of "collective responsibility" that he explores is predicated on the idea that there is some debate as to what responsibilities "agents" can be deemed to have. But there is no debate about young children: they are not decision-making agents, and they are not by any stretch of the imagination responsible for their own impoverishment. Barry hints at intergenerational issues by giving brief attention to "future individuals" (29), but these "future individuals"--presumably envisioned as future choice-makers and bearers of responsibility--are not the same as present-day children. The most pressing ethical issue about the debt crisis in many people's minds is, in fact--as evoked by the UNICEF report-whether today's children will survive long enough to make it to the future. Children as children are invisible.

\footnotetext{
${ }^{3}$ For comparison, the proportion under 15 in High Income countries is $14 \%$.
} 
Women, as well as children, are also often overlooked in discussions of international debt. To the extent that adult women are also excluded from family and national decision-making processes, the notion of the "agent" also fits women poorly. A number of feminist observers have noted that the problems caused by cuts in social services and contractions in public employment dictated by IMF-prescribed structural adjustment policies have often fallen most heavily on poor women (Bakker, 1994; Çagatay, Elson and Grown, 1996; Elson, 1991; Jaggar, 2002). "For example, if public health expenditures are cut back in order to restore a nation's "fiscal responsibility" in regard to its creditors, it is often women whose jobs are disproportionately cut, and women who end up with the burden of tending the sick at home in the absence of public services. Girl children may also be the first to be withdrawn from school if fees are imposed. Feminist economists Diane Elson and Nilufer Çagatay (2000) claim that the reason why women are so often overlooked in international affairs and development planning is because of what they call "male breadwinner bias" on the part of analysts and policymakers. ${ }^{5}$

Analysts have historically had a tendency to see countries as populated by male "heads-of-household." Only the people who, in their mind, might match the image of the "agent" or "citizen" of their economic and political theory-their expected "brown cow"-are visible to them. An "economic man" or "liberal man" framing of the problem, in short, excludes most of the relevant population from the analysis.

\section{Our Concern about Debt}

As a second problem, consider the boundaries that have often been put around discussions of ethics. Barry, in his essay, draws a line between "justice" conceived of as being about social rules, and "morality" which, he writes, is concerned with instances of character and behavior $(2005,22)$. His discussion, he says, will concentrate on the

\footnotetext{
${ }^{4}$ One must be careful, however, not to go overboard by maintaining that women are always and everywhere an especially victimized group compared to men. While Jaggar, for example, herself warns that neoliberal economic policies have harmed "not... all or only women" (2002), her claim that women were especially harmed by the loss of "wellpaid jobs" in the U.S. and global North since the 1970s is not borne out by a review of the history. Jaggar cites the fact that (by some accounts) the earnings gap between men and women in the U.S. widened (marginally) in 1998 and 1999 as support for her claim. In fact, however, many of the "good jobs" were lost earlier, during the 1980s, and were in heavy industrial occupations (such as autoworking) whose male-dominated nature had not been altered much by the increased entry of women into paid work. During the 1980s median real earnings for men nationwide fell, with the losses especially concentrated among less-educated men, while median real earnings for women, who were disproportionately employed in service occupations less affected by the trade-induced sectoral shifts, rose (Blau, Ferber, and Winkler, 2002, 258-230).

${ }^{5}$ Feminist observers have also noted the dearth or invisibility of women in national and international policy-making institutions, and argued for increased female representation in advisory and decision-making bodies. See Charlesworth, Chinkin and Wright (1991).
} 
former - as a good liberal philosophical analysis should. But are the two issues really so separable? Consider what happens when scholars turn the focus on ourselves. What explained our behavior, as scholars gathering for a conference?

Barry’s essay seems to try very hard to stay with a focus on impersonal justice. Most of the language in the essay is that of individual agency, impersonal contract, and generalized principles. The language used in one particular passage in that essay, however, reveals a broader type of concern:

[We] can have purely empirical disagreements about the justice of Collective Action Clauses for resolving debt problems because of divergent predictions of how this arrangement will serve our shared objectives of reducing poverty and ensuring that creditor's property rights are protected.

$$
\text { (22, emphasis added) }
$$

The passage briefly makes a bald assertion that "we" share certain substantive goals. Briefly, the fact that our scholarly work cannot be purely positive, but has necessarily normative aspects, is allowed to shine through. Perhaps a pure formalist would characterize the statement of "shared objectives" as a regrettable slip of the pen. And, in fact, a few lines later, there is a quick backing off of substantive issues and an apparent attempt to revert-by adding generality and using phrasing in the passive voice - to issues of pure form:

Yet [we may] still disagree about their justice because we attach different degrees of importance to the objectives of reducing poverty and protecting creditors' property rights, or some other considerations that are deemed ethically relevant. (22, emphasis added)

But the "slip" is a very interesting one. The model of rational contract, based on an image of self-interested "economic man," has no room in its core for the factor of otherinterest. Standard definitions of academic "objectivity” often assume an unbridgeable distance between the scholar and his or her values, and the object of study. ${ }^{6}$ Yet it is exceedingly difficult to talk in a reasonable way--as opposed to an economistic, rationalist way--about issues of ethics and poverty without expressing a real concern for people whose ability to live valuable lives has been severely circumscribed. ${ }^{7}$ If we really do not care, why should we scholars spend our time on this-foundations and universities sponsor such discussion? ${ }^{8}$

The spread of the rational choice model and its related epistemic values has created a regrettable tendency to try to cover over, "objectivize,” and bury in formality

\footnotetext{
${ }^{6}$ See E.F. Keller (1985), Nelson (1996) and Sen (1993) for critiques of this view of objectivity.

${ }^{7}$ The normative status of the assumed concern with creditor's interests is a bit more muddled. Is this intended to be supported as an end in itself or as a means to something else?

${ }^{8}$ The American Pragmatist school of philosophy offers a well-developed notion of scientific inquiry as motivated by our interests as a human community. For applications to economics, see Nelson (2003).
} 
our very sensible, wise, and human arisings of concern for people other than ourselves. If scholars take a brown cow view of ourselves, we recognize only our rational, individual side and fail to see our own emotional and connected side. We may know that as human beings we often act out of caring, but our academic ethical language is starved of the concepts and terms we need to bring these sensibilities and actions into conscious and deliberate analysis. Feminist theory can help.

\section{Maculinist Biases in Economics}

Feminist theory is often misunderstood. Many assume that is a political story about abject victimization. Others perceive feminist theorists as arguing for untenably vague, subjective, and ideologically-colored alternative approaches to philosophy, economics, or other fields - they think that feminists argue for taking a "feminine" and softer view of the world. In fact, feminist theories challenge standard approaches not because the standard disciplines are too hard and objective, but because they are not objective or rigorous enough. Mainstream approaches across the academic disciplines tend to be shot through with masculinist biases, limitations in perspective, and distortions that arise from narrow, dualistic thinking.

Contemporary mainstream (neoclassical) economics tends to hold in highest regard the epistemological or methodological values of precision, generality, and elegance. A failure to put the utmost effort into developing these characteristics would, it is believed, mean that our analysis would become only vague, particular, and messy. Economic agents are assumed to be autonomous, self-interested, and rational. Assuming otherwise would, it is believed, mean portraying people as entirely controlled, sentimental, and irrational-a view of "man" that seems insulting and backwards.

It is worth diverging a moment to investigate the source of this belief. John Stuart Mill's 1844 essay "On the Definition of Political Economy" is the point of origination of both the sense that economics should be a rigorous, deductive enterprise and the image of “economic man.” Political Economy, Mill thought, could only proceed as a "pure” and "abstract" science, resulting in general truths and timeless laws, if it posited a minimal set of starting principles such as those that form the base for geometry. In order to reach these principles, Mill relegated the parts of human experience having to do with bodies into the realm of physical science, leaving Political Economy concerned only with "phenomena of mind" (1844, 29, emphasis in the original). Issues of conscience or duty could be farmed out to the field of ethics, he thought, and life in society to "social economy." Political Economy would then deal only with "man [sic]...solely as a being who desires to possess wealth, and who is capable of judging of the comparative efficacy of means for obtaining that end.” $(1844,38)$. Thus “economic man” was born.

Note that all the parts of human nature that Mill excluded from "economic man" have feminine gender connotations in our Western culture. Mill’s bodiless, conscienceless, and a-social "man” was well described by Thomas Hobbes when he wrote, "Let us consider men . . . as if but even now sprung out of the earth, and suddenly, 
like mushrooms, come to full maturity, without all kind of engagement to each other" (quoted in Benhabib, 1987). Yet humans simply do not spring out of the earth. We are born as infants, nurtured and cared for as children, socialized into family and community norms, and have bodies that depend on the provision of nourishment and shelter. The tasks associated with these aspects of human life are often thought by economists and philosophers to be unimportant, intellectually uninteresting, or merely "natural.” They are, of course, also the tasks traditionally thought of as "women's work."

Pointing out these gender connotations is not intended to reify them, but to bring them from an unconscious level to a conscious level where they can be examined. Feminist scholars generally distinguish statements about sex from statements about gender, where sex refers to biological differences while gender refers to the meanings that societies construct on the base of those biological differences. The idea here is not at all to claim that women "are" more embodied, emotional, and connected. Rather, the point is that our social and cognitive association of these human characteristics with femininity (and inferiority) laps over into many areas of our culture, including the social construction of the academic disciplines (England, 2003; Harding, 1986; Keller, 1985; Mackenzie and Stoljar, 2000).

The allegiance to the assumption of "economic man" and the one-sided emphasis on precision within the field of economics reflect pure bias and a misunderstanding of the broader project of scientific inquiry (Ferber and Nelson, 1993, 2003). But to understand how to get beyond this, one needs to reevaluate the value system that gives rational choice analysis its support.

\section{Beyond "Economic Man”}

There is nothing wrong with aspiring to be precise, general, and elegant in one's analysis, nor with noticing that we are to some extent separate beings, each aware of our own interests and capable of using our minds. But a scholar's analysis is dangerously unbalanced if this is all that he or she does.

The argument that analysis that does not rely on "economic man" is somehow soft and inferior only works as long as neoclassical economists are allowed to pick and choose among epistemic values, elevating only those on whose scorecard their analysis performs well. Rather than accept simple dualistic categories such as precise/vague and elegant/messy, one can think about what qualities other than precision, generality, and elegance one might validly aim for in one's work.

Precision is, indeed, superior to vagueness, if that is the only dimension being considered. But the achievement of precision requires a certain narrowing of view, since purely precise methods can only deal with abstract and tightly delineated concepts. We also know the world through pattern recognition, metaphor, and other important cognitive capacities — often dismissed as merely "intuitive.” Attention to realism, context, and substance in fact lends breadth and depth to our investigations. In addition to the 
aforementioned values, we should also want our analysis to be rich, accurate, and realistic.

An analysis that as precise and elegant as it can be while not losing richness and realism is a very useful analysis. Overemphasizing one side or the other creates problems. In other words, neoclassical economists can make the seemingly precise, elegant, and general assertion that people are autonomous, rational, and self-interested (a.k.a. "cows in Vermont are brown") only because they ignore the dangers of being unduly narrow, inaccurate, and unrealistic. Yet a willingness to let go of some elegance in favor of gaining increased richness is not only advisable but, in the case of the analysis of international debt, urgently necessary.

We can similarly pull apart the assumption that if we do not characterize people as autonomous, self-interested, rational minds we will have no alternative but to treat them as totally controlled, sentimental, irrational sub-humans. All people, both male and female, are both individual and connected to others; endowed with both rational and emotional capacities; and have both minds and bodies. Treating people as detached, unemotional, and disembodied "mushroom men" is simply incorrect, and analysis based on such assumptions may steer us wrong on many fronts. In the analysis of international debt, for example, neglecting the fact that people have bodies and bodily needs can have fatal consequences.

\section{Rethinking our Concepts}

How are "contract," "ethics,” and "capital and debt” understood from within a brown cow, rational contract frame? How could these terms be better understood, if we took the time to look at our social and economic world more closely, more broadly, from a greater variety of perspectives, and with broader span of values and possible assumptions in mind?

\section{Rethinking Contracts}

Consider the relations among agents described in the rhetoric used in economist Barry Herman's background paper for the conference, "The Players and the Game of Sovereign Debt." There are "players" and a "game.” The "players" or parties have "interests" and the goal of reforms is to "clarify the rules" of the game (Herman 2005, 1). Defaults create serious problems because they are "a serious breach of property rights, which are considered an essential aspect of a well-functioning market economy" (17). Commentators are concerned about whether actions taken have been "fair" or "just" given the unequal bargaining powers of the parties (1). The IMF and World Bank play a role "something like the central overseer/umpire" for debt resolution in HIPCs (17).

There are at least two problems with this image. First, the "game" metaphor is predicated on a image of players who have at least some degree of agency. The language of games suggests strategy, like in chess, or pretend enactments, like in war "games," or even fun. I am afraid that, to a parent of a child stunted by poverty in an HIPC, this 
metaphor of "games" would likely be quite offensive. There is nothing pretend or playful in such a situation. Second, more deeply, the "umpire" image is predicated on the idea that a number of rules_-particularly the rules of the "market economy"-preexist and fundamentally bind the decisions that might be made about fairness. The "umpire” image suggests that the legal system is a neutral arbiter that follows principles rather than makes policy.

Such a view borrows heavily from economics, in that it borrows the rational choice contract frame, and uses the language of game theory, and puts the private market economy at center stage. Within the rational choice contract frame, contracts are considered to be private agreements freely entered into by agents. Contract law enters this picture primarily as a public means of enforcing such private agreements - that is, as a way of making the parties, now, live up to what they themselves voluntarily and rationally had, at some point in the past, committed to do. Only in extreme special cases might it be allowed that the bargaining powers of the agents could have been so unfair that a debt could be judged to be odious, unconscionable, or otherwise illegitimate. Only in such exceptional cases are the terms of the original contract called into question.

Feminist scholars have challenged such an image of contract law. Clare Dalton, for example, notices that "contract law describes itself as more private than public," and "as more about form than about substance" $(1985,1000)$. Yet, she suggests, this selfdescription merely covers over problems and inconsistencies rather than resolving them. The belief that law is merely about the public enforcement of private voluntary contracts, she claims, "distracts us from the political nature of drawing lines” between acceptable contracts and unacceptable ones $(1985,1038)$. In the real world it is equality in power that is the exceptional case, while large differences in power are endemic. The task of specifying the point at which presumably legitimate self-interested economic dealings between unequally situated parties shades over into unacceptable exploitation of one party by another is a determination that can only be drawn as a social and political decision. It is not just a marginal add-on to our analysis which we need only draw once in a while. Rather, determination of that line is part of the very foundation of our social, political, and economic life and, as such, is thoroughly amenable to ethical critique. ${ }^{9}$

Feminist legal scholar Gillian Hadfield (1998) has raised a further challenge to rational contract theory. Hadfield argues that the conventional idea that "when someone makes the choice to enter into a contract, she does so primarily to select a preferred future state of affairs" is fallacious. Rather than reflecting choices over future states, Hadfield argues, it may be that in agreeing to the contract the "chooser assessed her options in light of what the choice would express" in terms of the current state of affairs. In this case, richer notion of ethics and law must apply. If the contract was not a straightforward

${ }^{9}$ A similar argument regarding international debt has been advanced by Thomas Palley (2003) when he writes that the arguments from "contractual rights" in IMF documents are "specious." "Contractual rights," Palley claims, "are a legal construction, and they can and should be changed in accordance with what is deemed to be best for the public interest." 
rational, self-interested agreement concerning future outcomes, but rather had "expressive" aspects as well, then it is up to the law to evaluate what consequences in the future may, or may not, be attached. Applying Hadfield's insight, many contracts entered into by sovereign states can be seen as having such an "expressive” dimension. A nation may enter into a loan agreement as a signal of political alliance, or to indicate an attitude of cooperativeness with the export promotion policies of a more powerful country. A contract may, of course, be an expression of pure fear, a knuckling-under to hard-line tactics. Or it may be an expression of pro-market sentiments when such an expression is believed to be politically advantageous. Whether the government officials who signed the papers putting their countries in debt ever even half believed the idea that the funds would actually be helpful, or that their countries would be able to service and/or repay the debt, might be quite beside the point.

While feminist theorists are particularly sensitive to context and meaning of contracts, the literature on the "relational theory of contracts" may be illuminating as well. Originating in the work of legal scholars Ian Macneil and Stewart Macaulay, this theory sees contracting as taking place within a context of ongoing social relationships of cooperation for mutual gain (Macneil, 1968; Macaulay, 2000). Written contracts, relational contract theorists point out, are only the beginning of a relationship and the actual terms of the contract are often forgotten-or never even fully understood. Renegotiation, this literature points out, is the rule rather than the exception.

The relational aspects of debt contracts, in particular, have been recognized by a number of scholars, feminists among them. For example, a significant literature exists on the topic of "relational banking," which, as expressed by finance scholar Arnoud Boot, includes a recognition that bank-borrower relations may take the form of "a mutual commitment based on trust and respect” (2000,14). Kunibert Raffer (2005) describes how debtors and creditors often share have common interests - and how certain kinds of policies destroy those connections. Philosopher Elizabeth Anderson traces the frequent neglect of "the concrete social relations, motivations, and social meanings" of debt in scholarly writings to the "the excessively abstract, formal representations of freedom, efficiency, and markets in economic theory” (2004, 347). Debt contracts, Anderson points out, have historically included not only obligations to pay in money terms but also burdens of "moral opprobrium or social subordination" (2004, 347). And any serious study of financial markets reveals that debt contracts are far from sacrosanct. Even in the most smoothly functioning financial markets, lenders charge risk premia because they know that some of their contracts will require renegotiation and/or end in default.

Such approaches, of course, run up against the usual methodological biases. Macaulay, for example, writes of relational contract theory being more "messy" than the law-and-economics rational contract approach with its emphasis on "neatness," clarity, rules, and efficiency $(2000,803)$. But particularly in a discussion of ethics and debt contracts, can we afford to ignore the power, expressive, and other relational dimensions of contracts? 


\section{Rethinking Ethics}

In the "liberal man" view, ethics is a matter of abstract principles of justice. As mentioned earlier, Barry’s essay draws a line between "justice" conceived of as being about social rules and which will be discussed at length, and "morality" which is concerned with instances of character and behavior, and which will be ignored. Barry Herman's essay also discusses ethics in terms of "fairness" and "rules." Economists' methodological biases also make an appearance, as Barry expresses the belief that we could find the precise "social rule” for distributive justice that we are seeking by using "sum-ranking, maximin, or some indicator of inequality as an aggregation function for combining the relevant goods” (24). In these views, relations based on impersonal contract are seen as largely separable from rich relations among flesh-and-blood human beings.

Feminist theory has had a twenty year head start in trying to reintroduce the missing factor of interpersonal care and responsibility into the field of ethics. Carol Gilligan's In a Different Voice (1982) instigated a profoundly transformative line of feminist research. Gilligan had been researching the development of ethical thinking using Kohlberg's model of sequential stages. In that model, the ability to conceive of ethics in terms of universal principles of justice is considered to mark the pinnacle of ethical development. In one of Gilligan's studies, for example, subjects were presented with the "Heinz dilemma," a brief passage describing the situation of a man who must decide whether or not to steal a drug that he cannot afford to save his wife's life. According to the standard model, this was supposed to be seen as the story of a man's decision as to which moral rule--protection of life or protection of property--should logically take precedence. Yet Gilligan found that a number of her subjects would go off in other directions--questioning the morality of the druggist in not donating the drug, for example, or pondering whether Heinz would be able to take care of his wife if he were sent to jail. Such lines of thought were considered within the Kohlberg model to be extraneous tangents that demonstrated that the respondent was ethically immature and incapable of focusing on the correct moral principles. Gilligan saw something different. Gilligan saw in these responses a suggestion of a different but equally legitimate approach, in which the dilemma is perceived as a story of strained relationships among Heinz, his wife, and the druggist. ${ }^{10}$

Gilligan came to question the notion that there can only be a single path of maturation, and that justice and fairness are exhaustive of sophisticated moral thinking. She suggested that side by side with an "ethic of justice" lies an "ethic of care," that is, an ethic of responsibility towards other persons in relationships. While the justice ethic can be formulated in abstract rules, the care ethic is heavily contextual and dependent on the recognition of the particular needs of others. In the words of later commentator Seyla

${ }^{10}$ More controversially, Gilligan also initially claimed that the "justice" orientation was more typical among the male subjects of her original research, and the "care" orientation among females. The idea that the two ethical orientations are sex-linked has been called into question by many later researchers, whose work has shown that many people of either sex draw on both orientations. 
Benhabib, justice deals with our relations with the "generalized other" while care treats our relationships with the "concrete other" (1987). Justice is primarily concerned with maintaining fairness among equals, Gilligan said, while care is primarily concerned with maintaining equity and non-violence among people with different needs and abilities. Gilligan claimed that both ethical perspectives are necessary for mature moral decisionmaking. ${ }^{11}$

A concern that justice be done among approximately similarly-situated parties is, of course, an entirely legitimate aspect of ethics. What is illegitimate is assuming that all relationships fit this mold, so that issues of dependence, need, and our responsibilities towards others in all the variety of relationships in which we find ourselves, individually and corporately, can be shunted aside. Scholars may not have really forgotten about the children in HIPCs. But scholars need to work together to build a language of ethics that can be used to talk about them--and about us.

\section{Rethinking Capital and Debt}

In brown cow economic thinking, debt is something that agents take on when they want to make investments in productive capital. An agent will make a rational choice to borrow only if the profit (in the case of a company) or economic growth (in the case of a state) that is facilitated by the increase in capital can be expected to be sufficient to allow the debtor to pay back the investment loan with interest. The agent playing the role of creditor makes a similar rational decision. Needs, emotions, the behavior of others, and the passage of real time are considered irrelevant. Several passages in Herman's essay, for example, take the roles of governments and bank officers described by the rational choice model and infer that these are hence the "typical" or "normal" behavior of such agents in real life-a very questionable proposition (2005, 2, 6).

While feminist analysis of capital markets is in its infancy, there are certainly literatures on capital and debt that one might characterize as less masculinist-biased in that they take into account bodies as well as minds, emotions as well as reason, and social connection as well as independent action.

One such literature would be “old fashioned” religious discussions about the moral ramifications of debt and interest-taking. The prospect of commercial gain is not the only reason for taking out a loan, nor are loans always among equals. Jewish, Christian, and Islamic scriptures have harsh words for powerful people who, to increase their own wealth, exploit the less powerful through harsh economic treatment-even to the point of taking away their debtors' means of subsistence or forcing them into slavery. While contemporary mainstream economic theory dismisses the notion of "need" as not scientifically precise, recognition of people's needs for food, shelter, and self-

${ }^{11}$ To those who fail to see the relevance of personal relationships, or how deeply they are intertwined with principles, I like to suggest a small alteration to the story: What if it was not Heinz' wife who was sick, but his neighbor, or perhaps a total stranger? What happens to the "principle of life over property"? 
determination would bring the consideration of human rights and human dignity back into our analysis.

The idea that investment behavior is normally and predominantly detached and rational has been challenged by at least three major waves of economic theories. Most famous, perhaps, is John Maynard Keynes $(1936,161)$ notion of “animal spirits,” or the idea that general waves of overweening optimism and pessimism in investment are behind the booms and crashes we observe on a macroeconomic scale. John R. Commons, a founder of the Institutionalist school of economics, similarly asserted that "Not logic, but fear and hope are fundamental” in discussions of debt and credit $(1950,105)$. Most recently, the school of "behavioral finance" led by Robert J. Shiller (2000) has incorporated insights from social psychology into analysis of real world behavior in capital markets. The "emotional contagion" of greed and fear, the "herd behavior" of banks or governments who rush to loan because others are loaning-and then rush to pull out loans because others are pulling out loans--and other sorts of complex nonrational or irrational dynamics are offered to explain what are often extremely bumpy, unpredictable, and even catastrophic real world market swings.

Some grudgingly accept such phenomena as explaining “unusual” cases while hanging on to a core model of rationality. But all evidence (considered with an open mind) suggests that such behavior is within the normal. People are-necessarily, not merely contingently--emotional as well as rational, and are deeply connected to others through lines of communication, trust, and emulation. It is no surprise, then, that these characteristics should be reflected in human behavior on financial markets. The developing field of "social studies of finance," for example, sees financial markets in both their irrational and rational dimensions as thoroughly part of culture (de Goede, 2005).

The "normal” in financial markets includes considerable doses of need, greed, foolishness, irresponsibility, speculation, fraud, predation, emulation, cozying-up, and herd behavior. Realistic and useful proposals to reform capital markets must take into account these factors, not brush them under the rug by assuming brown cows.

\section{Conclusion}

The economistic way of viewing the problem of international debt is to see it as, at base, a situation in which independent, rational agents are bound by voluntary market contracts. The problem of ethics is, correspondingly, seen as the problem of coming up with appropriate rules or principles with which to arbitrate disputes. But there are more people in this world than only those who may appear as independent and rational--just as there are more cows in Vermont than the first one seen from a train. And, just as importantly, actors who may appear to be conveniently singular, independent, and rational from the perspective of one viewer, reveal their less analytically convenient plural, interdependent, and emotional sides when seen from other perspectives. Our 
analysis will only help provide appropriate responses to the debt crisis if we can take off the blinders put on us by the rational choice contract approach and its epistemic values.

A few key qualities of a more adequate approach can be noted. It should take into account children and women. It should take into account the physical repercussions of debt on the bodies of people deprived of food and health care and on the sustaining ability of the environment. Its assumptions about behavior should include emotion and interdependence as well as rationality and individuality. Ethical questions should be phrased in the language of responsiveness and responsibility as well as in the language of principles and rules. Finally, contracts and market institutions should be recognized as located within complex networks of social and political relations, including relations of power and--one can hope--care. Only with a more adequate way of understanding the debt crisis can we hope to contribute to the design of more adequate institutions and to more compassionate and humane conduct in international financial affairs.

Julie A. Nelson is a Senior Research Associate at the Global Development and Environment Institute at Tufts University, USA. Inquiries can be directed to Julie.Nelson@tufts.edu. 


\section{REFERENCES}

Anderson, Elizabeth. 2004. "Ethical Assumptions of Economic Theory: Some Lessons from the History of Credit and Bankruptcy," Ethical Theory and Moral Practice 7(4): 347-360.

Bakker, Isabella (ed.) 1994. The Strategic Silence: Gender and Economic Policy. London: Zed Books.

Barry, Christian. 2005. “Ethical Issues Relevant to Debt.” Background note, Ethics and Debt Project, New School University and the Carnegie Council on Ethics and International Affairs.

Benhabib, Seyla. 1987. The generalized and concrete other: The Kohlberg-Gilligan controversy and feminist theory. Pp. 77-95 in Seyla Benhabib and Drucilla Cornell (eds), Feminism as Critique: On the Politics of Gender. Minneapolis: University of Minnesota Press.

Blau, Francine D., Marianne A. Ferber and Anne E. Winkler. 2002. The Economics of Men, Women and Work, $4^{\text {th }}$ ed. Upper Saddle River: Prentice Hall.

Boot, Arnoud W. A. 2000. "Relationship Banking: What Do We Know?" Journal of Financial Intermediation 9: 7-25.

Çagatay, Nilufer, Diane Elson and Caren Grown. 1996. “Introduction,” special issue on Gender, Adjustment and Macroeconomics, World Development, 23 (11), November: 1827-1938.

Charlesworth, Hilary, Christine Chinkin and Shelley Wright. 1991. "Feminist Approaches to International Law,” American Journal of International Law 85: 613-645.

Commons, John R. 1950. The Economics of Collective Action. Madison: University of Wisconsin Press. Chapter 8, http://members.shaw.ca/compilerpress1/Anno\%20Commons\%20Futurity.htm, accessed 8/8/05.

Dalton, Clare. 1985. “An Essay in the Deconstruction of Contract Doctrine,” Yale Law Journal 94(5): 997-1114.

de Goede, Marieke. 2005. "Resocializing and Repoliticising Financial Markets: Contours of Social Studies of Finance.” Economic Sociology: European Electronic Newsletter 6(3). http://econsoc.mpifg.de/current/6-3art3.asp (accessed 8/26/2005)

Elson, Diane (ed.). 1991. Male Bias in the Development Process. Manchester: Manchester University Press.

Elson, Diane and Nilufer Çagatay. 2000. “The Social Content of Macroeconomic Policies,” World Development 28(7): 1347-1354.

England, Paula. 2003. "Separative and Soluble Selves: Dichotomous Thinking in Economics," in Feminist Economics Today: Beyond Economic Man, ed. Marianne A. Ferber and Julie A. Nelson, University of Chicago Press, pp. 33-60.

Ferber, Marianne A. and Julie A. Nelson. 1993. Beyond Economic Man: Feminist Theory and Economics. University of Chicago Press.

Ferber, Marianne A. and Julie A. Nelson. 2003. Feminist Economics Today: Beyond Economic Man. University of Chicago Press. 
Gilligan, Carol. 1982. In A Difference Voice: Psychological Theory and Women's Development. Cambridge: Harvard University Press.

Hadfield, Gillian K. 1998. "An Expressive Theory of Contract: Form Feminist Dilemmas to a Reconceptualization of Rational Choice in Contract Law.” Univ. of Pennsylvania Law Review 146:1235-1285.

Harding, Sandra. 1986. The Science Question in Feminism. Ithaca: Cornell University Press.

Herman, Barry. 2005. “The Players and the Game of Sovereign Debt.” Background note, Ethics and Debt Project, New School University and the Carnegie Council on Ethics and International Affairs.

Keller, Evelyn Fox. 1985. Reflection on Gender and Science. New Haven, Conn: Yale University Press.

Keynes, John Maynard. 1936. The General Theory of Employment, Interest and Money NY: Harcourt, Brace and Company.

Jaggar, Alison M. 2002. “A Feminist Critique of the Alleged Southern Debt.” Hypatia 17(4): 119-145.

Macaulay, Stewart, 2000. "Relational Contracts Floating on a Sea of Custom? Thoughts about the Ideas of Ian Macneil and Lisa Bernstein. Northwestern University Law Review 94(3): 775-804.

Mackenzie, Catriona and Natalie Stoljar, eds. 2000. Relational Autonomy: Feminist perspectives on Autonomy, Agency and the Social Self. Oxford: Oxford University Press.

Mcneil, Ian. 1968. Contracts: Instruments for Social Co-operation. South Hackensack, N.J: F. B. Rothman.

Meagher, Gabrielle and Julie A. Nelson. 2004. "Survey Article: Feminism in the Dismal Science.” Journal of Political Philosophy 12(1):102-126.

Mill, John Stuart, 1844. Essay V: On the definition of political economy; and on the method of investigation proper to it, in Essays on Some Unsettled Questions of Political Economy. London: Longmans, Green, Reader, and Dyer Co., 1874. Second edition. http://www.econlib.org/library/Mill/mlUQP5.html.

Nelson, Julie A. 1996. Feminism, Objectivity and Economics. NY: Routledge.

Nelson, Julie A. 2003. "Confronting the Science/Value Split: Notes on Feminist Economics, Institutionalism, Pragmatism and Process Thought." Cambridge Journal of Economics 27(1), 49-64.

Palley, Thomas I. 2003. "Sovereign Debt Restructuring: What is the Problem?” Paper given at a conference on the Sovereign Debt Restructuring Mechanism at the IMF, January. http://www.imf.org/External/NP/EXR/seminars/2003/sdrm/pdf/palley.pdf accessed 9/15/2005.

Kunibert Raffer, "Risks of Lending and Liability of Lenders." Presented at the conference "The Problem of Sovereign Debt," sponsored by New School University and the Carnegie Council on Ethics and International Affairs, New York, November 1-2, 2005

Sen, Amartya. 1993. "Positional Objectivity,” Philosophy \& Public Affairs 22: 126-45. Shiller, Robert J. 2000. Irrational Exuberance, Princeton University Press. Stiglitz, Joseph. 2002. Globalization and Its Discontents, WW Norton \& Company. 
UNICEF. 1989. The State of the World's Children. Quoted in UNICEF, The Progress of Nations 1999. http://www.unicef.org/pon99/debtdat2.htm accessed 9/12/2005.

World Bank. 2005. World Development Indicators On-Line. 
The Global Development And Environment Institute (GDAE) is a research institute at Tufts University dedicated to promoting a better understanding of how societies can pursue their economic goals in an environmentally and socially sustainable manner. GDAE pursues its mission through original research, policy work, publication projects, curriculum development, conferences, and other activities. The "GDAE Working Papers" series presents substantive work-in-progress by GDAE-affiliated researchers. We welcome your comments, either by e-mail directly to the author or to G-DAE,

Tufts University, 44 Teele Ave., Medford, MA 02155 USA; tel: 617-627-3530; fax: 617-627-2409; e-mail: gdae@tufts.edu; website: http://ase.tufts.edu/gdae.

\section{Papers in this Series:}

00-01 Still Dead After All These Years: Interpreting the Failure of General Equilibrium Theory (Frank Ackerman, November 1999)

00-02 Economics in Context: The Need for a New Textbook (Neva R. Goodwin, Oleg I. Ananyin, Frank Ackerman and Thomas E. Weisskopf, February 1997)

00-03 Trade Liberalization and Pollution Intensive Industries in Developing Countries: A Partial Equilibrium Approach (Kevin Gallagher and Frank Ackerman, January 2000)

00-04 Basic Principles of Sustainable Development (Jonathan M. Harris, June 2000)

00-05 Getting the Prices Wrong: The Limits of Market-Based Environmental Policy (Frank Ackerman and Kevin Gallagher, September 2000)

00-06 Telling Other Stories: Heterodox Critiques of Neoclassical Micro Principles Texts (Steve Cohn, August 2000)

00-07 Trade Liberalization and Industrial Pollution in Mexico: Lessons for the FTAA (Kevin Gallagher, October 2000) (Paper withdrawn- see www.ase.tufts.edu/gdae/ for details)

00-08 Waste in the Inner City: Asset or Assault? (Frank Ackerman and Sumreen Mirza, June 2000)

01-01 Civil Economy and Civilized Economics: Essentials for Sustainable Development (Neva Goodwin, January 2001)

01-02 Mixed Signals: Market Incentives, Recycling and the Price Spike of 1995. (Frank Ackerman and Kevin Gallagher, January 2001)

01-03 Community Control in a Global Economy: Lessons from Mexico’s Economic Integration Process (Tim Wise and Eliza Waters, February 2001)

01-04 Agriculture in a Global Perspective (Jonathan M. Harris, March 2001)

01-05 Better Principles: New Approaches to Teaching Introductory Economics (Neva R. Goodwin and Jonathan M. Harris, March 2001)

01-06 The \$6.1 Million Question (Frank Ackerman and Lisa Heinzerling, April 2002)

01-07 Dirt is in the Eye of the Beholder: The World Bank Air Pollution Intensities for Mexico (Francisco Aguayo, Kevin P. Gallagher, and Ana Citlalic González, July 2001)

01-08 Is NACEC a Model Trade and Environment Institution? Lessons from Mexican Industry (Kevin P. Gallagher, October 2001)

01-09 Macroeconomic Policy and Sustainability (Jonathan M. Harris, July 2001) 
02-01 Economic Analysis in Environmental Reviews of Trade Agreements: Assessing the North American Experience. (Kevin Gallagher, Frank Ackerman, Luke Ney, April 2002)

03-01 Read My Lips: More New Tax Cuts-The Distributional Impacts of Repealing Dividend Taxation (Brian Roach, February 2003)

03-02 Macroeconomics for the $21^{\text {st }}$ Century (Neva R. Goodwin, February 2003)

03-03 Reconciling Growth and the Environment (Jonathan M. Harris and Neva R. Goodwin, March 2003)

03-04 Current Economic Conditions in Myanmar and Options for Sustainable Growth (David Dapice, May 2003)

03-05 Economic Reform, Energy, and Development: The Case of Mexican Manufacturing (Francisco Aguayo and Kevin P. Gallagher, July 2003)

03-06 Free Trade, Corn, and the Environment: Environmental Impacts of US-Mexico Corn Trade Under NAFTA

03-07 Five Kinds of Capital: Useful Concepts for Sustainable Development (Neva R. Goodwin, September 2003)

03-08 International Trade and Air Pollution: The Economic Costs of Air Emissions from Waterborne Commerce Vessels in the United States (Kevin P. Gallagher and Robin Taylor, September 2003)

03-09 Costs of Preventable Childhood Illness: The Price We Pay for Pollution (Rachel Massey and Frank Ackerman, September 2003)

03-10 Progressive and Regressive Taxation in the United States: Who's Really Paying (and Not Paying) their Fair Share? (Brian Roach, October 2003)

03-11 Clocks, Creation, and Clarity: Insights on Ethics and Economics from a Feminist Perspective (Julie A. Nelson, October 2003)

04-01 Beyond Small-Is-Beautiful: A Buddhist and Feminist Analysis of Ethics and Business (Julie A. Nelson, January 2004)

04-02 The Paradox of Agricultural Subsidies: Measurement Issues, Agricultural Dumping, and Policy Reform (Timothy A. Wise, February 2004)

04-03 Is Economics a Natural Science? (Julie Nelson, March 2004)

05-01 The Shrinking Gains from Trade: A Critical Assessment of Doha Round Projections (Frank Ackerman, October 2005)

05-02 Understanding the Farm Problem: Six Common Errors in Presenting Farm Statistics (Timothy A. Wise, March 2005)

05-03 Securing Social Security: Sensitivity to Economic Assumptions and Analysis of Policy Options (Brian Roach and Frank Ackerman, May 2005)

05-04 Rationality and Humanity: A View from Feminist Economics (Julie A. Nelson, May 2005)

05-05 Teaching Ecological and Feminist Economics in the Principles Course (Julie A. Nelson and Neva Goodwin, June 2005)

05-06 Policy Space for Development in the WTO and Beyond: The Case of Intellectual Property Rights (Ken Shadlen, November 2005)

05-07 Identifying the Real Winners from U.S. Agricultural Policies (Timothy A. Wise, December 2005)

06-01 The Missing Links between Foreign Investment and Development: Lessons from Costa Rica and Mexico (Eva A. Paus and Kevin P. Gallagher, February 2006)

06-02 The Unbearable Lightness of Regulatory Costs (Frank Ackerman, February 2006) 
06-03 Feeding the Factory Farm: Implicit Subsidies to the Broiler Chicken Industry (Elanor Starmer, Aimee Witteman and Timothy A. Wise, June 2006)

06-04 Ethics and International Debt: A View from Feminist Economics (Julie A. Nelson, August 2006) 